\title{
Pressurized Gas Beam Monitor for Extremely High Intensities
}
Cooperative Research and Development Agreement Final Report

CRADA Number: FRA-2015-0012

Fermilab Technical Contact: Katsuya Yonehara

Summary Report

October 2, 2016 


\section{NOTICE}

This report was prepared as an account of work sponsored by an agency of the United States government. Neither the United States government nor any agency thereof, nor any of their employees, makes any warranty, express or implied, or assumes any legal liability or responsibility for the accuracy, completeness, or usefulness of any information, apparatus, product, or process disclosed, or represents that its use would not infringe privately owned rights. Reference herein to any specific commercial product, process, or service by trade name, trademark, manufacturer, or otherwise does not necessarily constitute or imply its endorsement, recommendation, or favoring by the United States government or any agency thereof. The views and opinions of authors expressed herein do not necessarily state or reflect those of the United States government or any agency thereof.

Available electronically at http://www.osti.gov/bridge

Available for a processing fee to U.S. Department of Energy and its contractors, in paper, from: U.S. Department of Energy Office of Scientific and Technical Information P.O. Box 62

Oak Ridge, TN 37831-0062

phone: 865.576 .8401

fax: 865.576 .5728

email: mailto:reports@adonis.osti.gov

Available for sale to the public, in paper, from:

U.S. Department of Commerce

National Technical Information Service

5285 Port Royal Road

Springfield, VA 22161

phone: 800.553.6847

fax: 703.605 .6900

email: orders@ntis.fedworld.gov

online ordering: http://www.ntis.gov/ordering.htm 
In accordance with Requirements set forth in Article X of the CRADA, this document is the final CRADA report, including a list of Subject Inventions, to be forwarded to the Office of Science and Technical Information as part of the commitment to the public to demonstrate results of federally funded research.

CRADA number: $\quad$ FRA-2015-0012

CRADA Title: $\quad$ Pressurized Gas Beam Monitor for Extremely High Intensities

Parties to the Agreement: MuPlus, Inc. and Fermi Research Alliance, LLC

\section{Abstract of CRADA work:}

The performance of a gas-filled RF resonator will be numerically simulated to evaluate the sensitivity of permittivity measurements and the effectiveness of calibration strategies. An entire resonator-hodoscope system will be designed and a demonstration test prepared.

\section{Summary of Research Results:}

1. The performance of a gas-filled RF cavity was numerically simulated to evaluate the sensitivity of permittivity measurements and the effectiveness of calibration strategies:

- The fundamental processes in the production of ions when a beam of ions passes through a gas

- Simulations of beam particles passing through a gas RF cavity

- Simulations of frequency shift in a RF cavity as a function of beam position

- Studies of RF energy consumption by the RF cavity as a function of beam position to determine position measurement sensitivity

- Studies of addition of electronegative dopants to the gas and their effects on mobility of the heavy ions in the RF cavity

- Simulated beam profiles after the LBNF target, including secondary particles produced

- Simulation of LBNF conditions, such as low primary beam energy, long target and empty target. The range covers the expected beam intensities in NuMI and LBNF.

\section{An RF cavity-beam profile system was conceived with corresponding subsystem}

\section{demonstration tests:}

- including the RF source, waveguide, and data acquisition system -descriptions given above in this narrative

- experimental plans to utilize intense beam facilities, MTA, FTBF and NuMI at Fermilab for a Phase II SBIR Proposal 
4 Final Report for CRADA FRA-2015-0012

In addition, we presented the first evaluation of this novel hadron monitor at IPAC 2015.

Related Reports, Publications, and Presentations:

IPAC 2015 paper MOPMA028

Subject Inventions listing:

NONE

Report Date: October 2, 2016

Technical Contact at Fermilab: Katsuya Yonehara

This document contains NO confidential, protectable or proprietary information.

October 2, 2016 